\title{
Thermal regime of a valley glacier, Erikbreen, northern Spitsbergen
}

\author{
RUNE STRAND ØDEGÅRD, SVEIN-ERIK HAMRAN, PER HELGE B $\emptyset$, BERND ETZELMÜLLER, GEIR VATNE \\ and JOHAN LUDVIG SOLLID
}

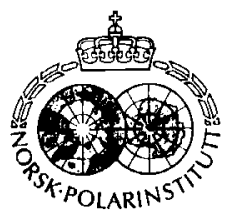

\begin{abstract}
Ødegård, R. S., Hamran, S.-E., Bø, P. H., Etzelmüller, B., Vatne, G. \& Sollid, J. L. 1992: Thermal regime of a valley glacier, Erikbreen, northern Spitsbergen. Polar Research 11(2), 69-79.

The thermal regime of the valley glacier, Erikbreen, northern Spitsbergen $\left(79^{\circ} 40^{\prime} \mathrm{N}, 12^{\circ} 30^{\prime} \mathrm{E}\right)$ was studied using radio-echo sounding and temperature measurements from eight borcholes ranging from 13.5 to $24 \mathrm{~m}$. Radar images indicate a glacicr with a two-laycred thermal structure. A surface layer of cold ice, 20 to $60 \mathrm{~m}$ thick along the centre flow line, extends from an altitude above equilibrium line to the glacier front. This layer represents 20 to $35 \%$ of the glacier thickness, except at the floating front, where the cold layer is about $50 \%$. The ice beneath the cold surface layer is interpreted to be temperate. Cold-based areas exist near the glacier margin and in some locations in the accumulation area: the ice is interpreted to be entirely temperate in central parts of the accumulation area at high altitude. Freezing of temperate icc at the basc of the cold surface layer is probably the main mechanism of cold ice formation in the frontal parts of Erikbreen. Calculated heat fluxes based on the borchole measurements show that a steady state cold layer 25 to $30 \mathrm{~m}$ thick is likely, assuming a surface melting of $1.7 \mathrm{~m} / \mathrm{y}$ and a maximum water content of $3 \%$. In the frontal parts the calculated mean annual upward heat flux at 10 to $15 \mathrm{~m}$ depth is roughily $0.6 \mathrm{~W} / \mathrm{m}^{2}$.
\end{abstract}

R. S. Odegård, P. H. Bø, B. Etzelmüller, G. Vatne and J. L. Sollid, Department of Physical Geography, University of Oslo, P.O. Box 1042 Blindern. N-0316 Oslo, Norway; S.-E. Hamran, Environmental Surveillance Technology Program, P.O. Box 89, N-2001 Lillestrom. Norway.

\section{Introduction}

Previous measurements of glacier ice temperatures have shown that several glaciers of the Svalbard archipelago have a cold surface layer. Schytt (1969) presents an early intuitive statement on the subpolar nature of these ice masses. Liestøl (1976) gives a general description of the thermal regime of glaciers, and relates the regime to permafrost conditions in Svalbard. Several $10 \mathrm{~m}$ depth temperatures available from the ablation area of Finsterwalderbreen (Fig. 1) demonstrate that the surface is cold (Nixon et al. 1985). Measurements in deep boreholes in Austre Brøggerbreen, Midre Lovénbreen and Kongsvegen near Ny-Ålesund (Fig. 1) in Spitsbergen document a cold surface layer overlying a temperate layer (Bjørnsson et al. unpubl.; Hagen, Norsk Polarinstitutt, unpubl.).

Radio-echo sounding (Dowdeswell et al. 1984a, b; Kotlyakov \& Macheret 1987; Bamber 1987a, b; Bjørnsson et al. unpubl.) show that an internal reflection horizon is common on Svalbard glaciers. This horizon has been interpreted to be a boundary between surface cold ice and deeper ice containing liquid water. Water inclusions are known to have a strong influence on the absorption and scattering of radio waves, depending on frequency and bandwidth (Smith \& Evans 1972). In the most recent work by Bjørnsson et al. (unpubl.), the results from radio-echo sounding are compared with thermistor measurements in several deep boreholes in glaciers in the vicinity of $\mathrm{Ny}$-Ålesund. These data indicate that the presence of temperate ice can be mapped based on the backscatter from water inclusions, and that the internal reflection horizon can be interpreted as the actual transition zone between cold and temperate ice. However, radio-echo data and temperature measurements from Austre Brøggerbreen indicate that it is difficult to detect a thin layer of temperate ice close to the bedrock. The interpretation of the radio-echo data presented in this paper is similar to interpretations from Storglaciären in Sweden (Holmlund \& Eriksson 1989).

The aim of our study was to map the extent of cold ice in a polythermal glacier using radio-echo sounding and ice temperature measurements with thermistor cables. Based on the temperature data, the mean annual temperature gradient and heat flux at 10 to $15 \mathrm{~m}$ depth were estimated. This then 
led to a discussion of the mechanisms controlling the extent and thickness of the cold surface layer of Erikbreen.

\section{Location and description of Erikbreen}

Erikbreen is situated on the north shore of Liefdefjorden on the northern coast of Spitsbergen $\left(79^{\circ} 40^{\prime} \mathrm{N}, 12^{\circ} 30^{\prime} \mathrm{E}\right)$ (Fig. 1). The nearest meteorological station is in $\mathrm{Ny}$-Allesund, $80 \mathrm{~km}$ to the south, where the mean annual air temperature is $-6.0^{\circ} \mathrm{C}(1971-1988)$ and average July and August temperatures are $5.2^{\circ} \mathrm{C}$ and $4.1^{\circ} \mathrm{C}$, respectively. Permafrost depths are known to vary from 150 to $500 \mathrm{~m}$ (Liestøl 1976).

Glaciological investigations on Erikbreen were undertaken in 1990, 1991 and 1992. Radio-echo sounding took place in the spring of 1991. In addition to mapping the thermal regime, studies were also carried out on mass balance, ice surface flow, water discharge, suspended sediment load, dissolved material, and glacier channel geometry (Vatne et al. 1992; Etzelmüller et al. in press).

Erikbreen is a valley glacier of $9.0 \mathrm{~km}^{2}$ (1990)

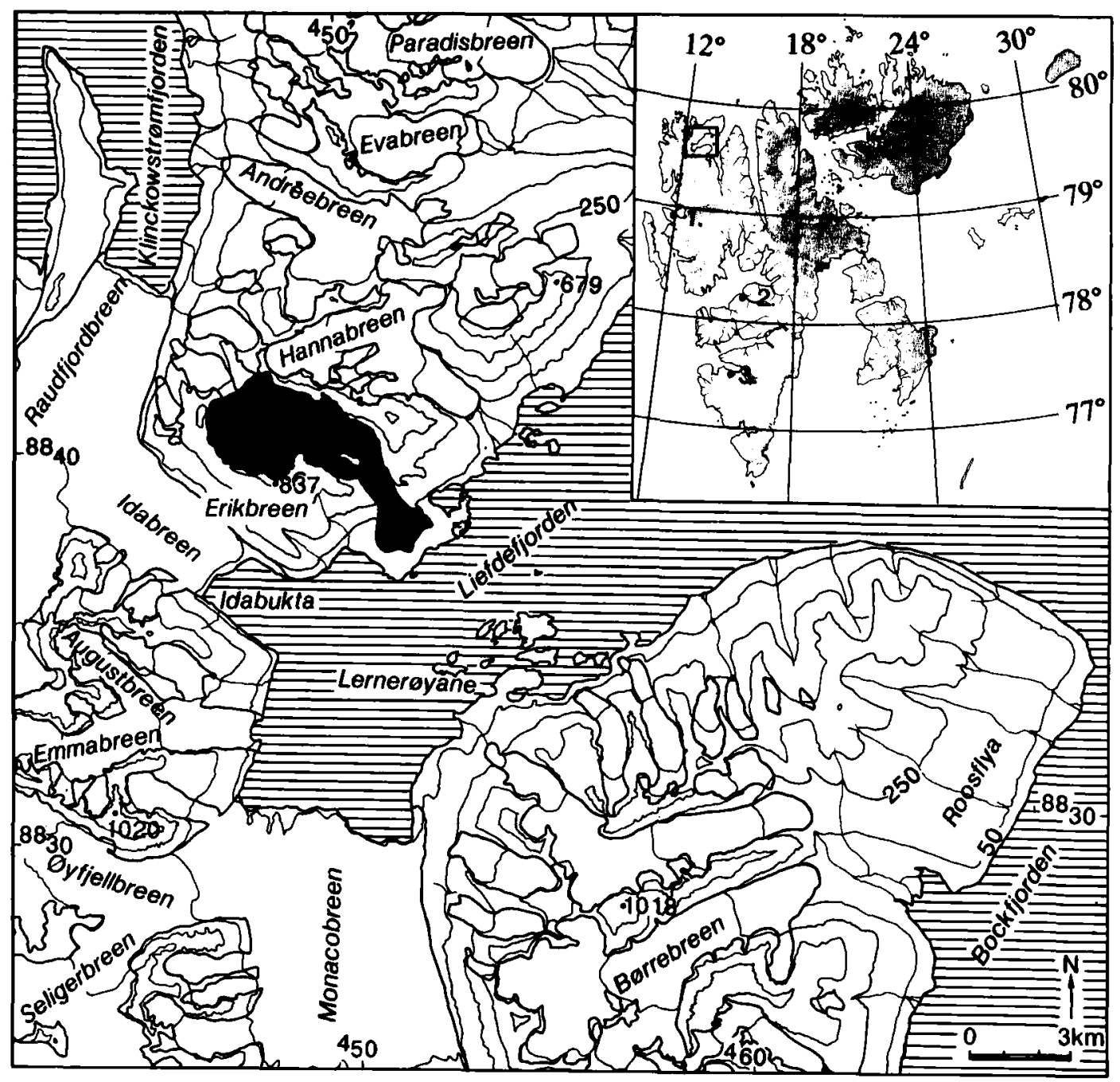

Fig. 1. Location of Erikbreen. Map compiled from base map 1:100000, Norsk Polarinstitutt. Inset map: 1. Ny-Ålesund. 2. Longyearbyen. 3. Finsterwalderbreen. 
Fig. 2. Map of Erikbreen showing the radar scctions and sites where measurements were made. Shaded area is a nunatak. Temperature measurements were made at sites $1,2,3$, $7.9,10,11$ and 12 .

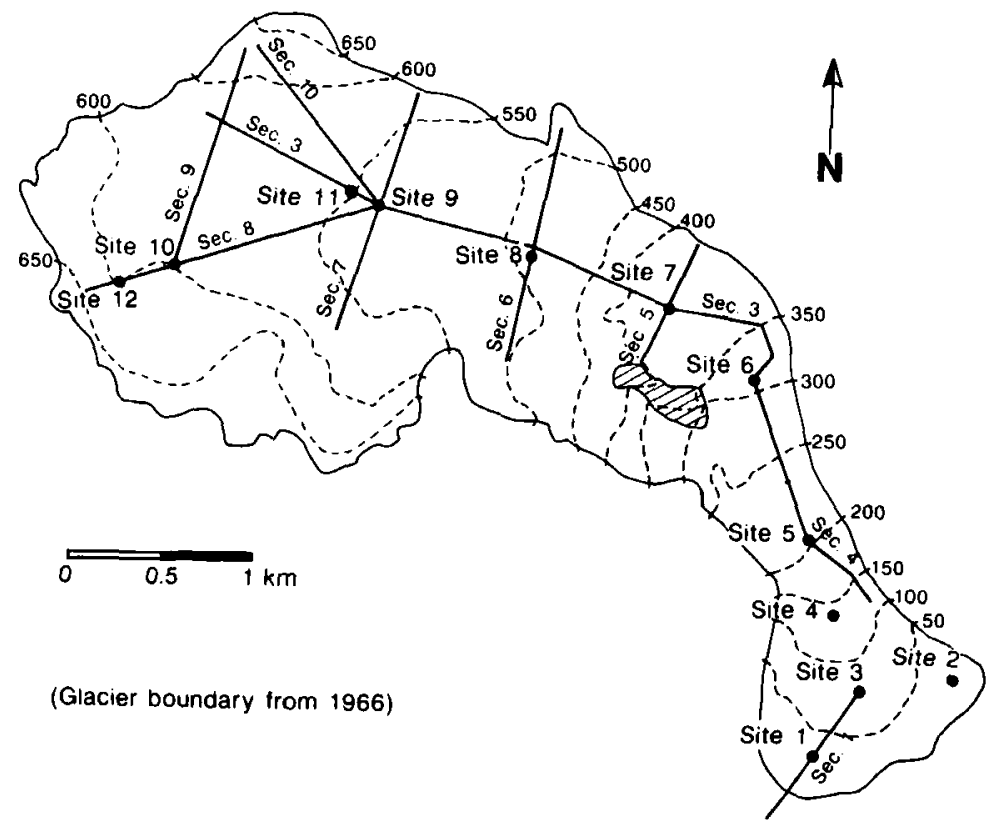

with a piedmont-like front (Fig. 2). The total drainage basin area is $12.4 \mathrm{~km}^{2}$. The equilibrium line altitude was at $550 \mathrm{~m}$ a.s.l. in 1990 and at $340 \mathrm{~m}$ a.s.l. in 1991. Based on comparison with long-term measurements made on Austre Brøggerbreen near $\mathrm{Ny}$-Ålesund, the summer balances in 1990 and 1991 were probably close to the maximum and minimum years respectively (Hagen \& Liestøl 1990; Hagen pers. commun.). The summer balance from 11 July 1990 to the end of the season was $-0.95 \mathrm{~m}$. In 1991 the summer balance from the start of the melting season through 18 August was $-0.46 \mathrm{~m}$. Net surface melting of ice close to the terminus is 1.7 to $2.3 \mathrm{~m} / \mathrm{y}$.

Erikbreen has probably been retreating since the beginning of the century (Lefauconnier \& Hagen 1990), and parts of its front now terminate in a lake dammed by large ice-cored moraines (Fig. 3). The glacier had a much larger extent in 1910 when the front was at the upglacier side of the ice-cored moraines (photograph, Norsk Polarinstitutt archives).

Maximum ice surface velocities measured in 1990 and 1991 were $0.16 \mathrm{~m} /$ day. This is about one order of magnitude higher than on other Svalbard glaciers of the same size, such as nearby Hannabreen as well as Austre Brøggerbreen and Midre Lovénbreen near Ny-Ålesund (Liestøl 1988; Etzelmüller et al. in press).

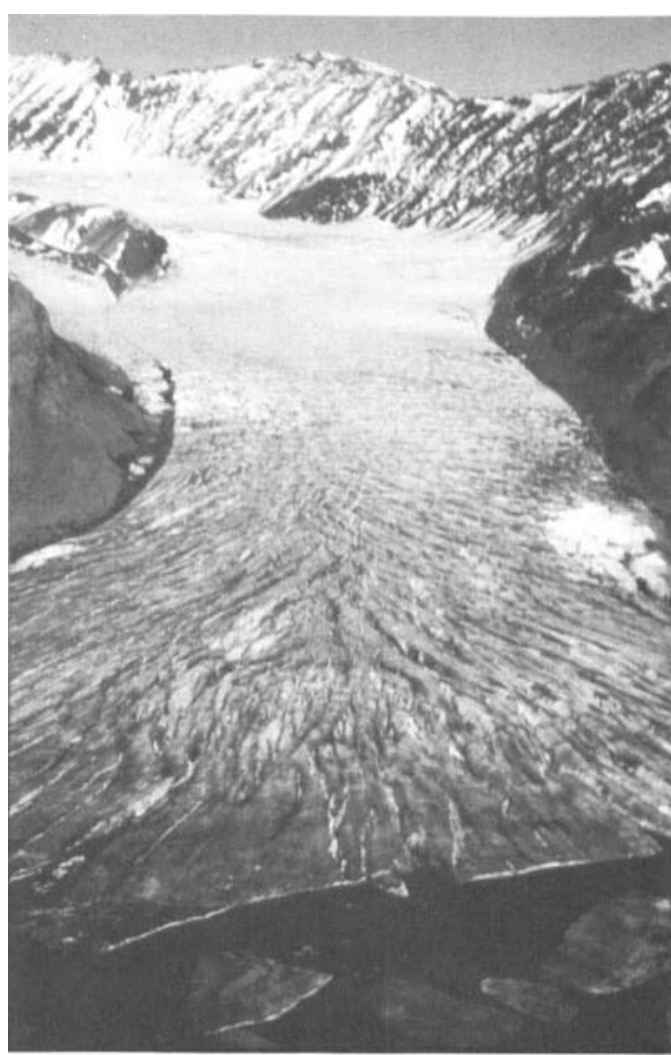

Fig. 3. Oblique air photo from the crevassed frontal part of Erikbreen (17 August 1990). Snow on the glacier is from a snow fall in early August (Photo: Norsk Polarinstitutt). 


\section{Methods of mapping the thermal regime}

The thermal regime was mapped with the use of radio-echo sounding and direct measurements with thermistors in eight boreholes 13.5 to $24 \mathrm{~m}$ in depth. In addition, temperatures at the interface between winter accumulation and ice or firn were measured at 21 sites along a profile close to the centre flow line before the start of the surface melt in the spring of 1991.

The radar system used is a time-gated synthetic pulse radar developed by the Royal Norwegian Council for Scientific and Industrial Research, Environmental Surveillance Technology Program (Hamran 1989). The radar and antennae were mounted on a sledge pulled by a snowmobile. The antennae were spaced approximately $2.5 \mathrm{~m}$ apart on a glassfibre rod attached to the sledge in a transverse position. The mapping speed was about $20 \mathrm{~km} /$ hour, depending on surface conditions. A portable generator was used as a power source.

The frequency bandwidth of the system is from $0.1 \mathrm{Mhz}$ to $3 \mathrm{GHz}$, thus covering the total frequency band needed for geophysical investigations. The antennae are the band-limiting factor for the sounding equipment. On Erikbreen, a 5$20 \mathrm{Mhz}$ resistively loaded dipole antenna was used to map the subglacial bedrock. Backscattering from bedrock was lost at depths below $230 \mathrm{~m}$, probably due to the antenna-snowmobile-sledge configuration. This problem had never been observed before. To map water inclusions in the glacier, $320-370 \mathrm{MHz}$ Yagi antennae were used. The horizontal distance between each measurement, controlled by a wheel on the sledge, was $4.2 \mathrm{~m}$ with the Yagi antennae and $8.4 \mathrm{~m}$ with the dipoles. To map the 1990/1991 snow accumulation and the upper firn layers, high resolution measurements were made with log-periodic antennae with frequencies from 1-3 GHz.

In the data reduction the dielectric constant of ice was assumed to be 3.2 , giving a phase velocity of $168 \mathrm{~m} / \mu \mathrm{s}$. A phase velocity of $230 \mathrm{~m} / \mu \mathrm{s}$ was used for snow and $202 \mathrm{~m} / \mu \mathrm{s}$ for firn in the reduction of the $1-3 \mathrm{GHz}$ data.

In addition to the radar survey, eight boreholes were drilled at altitudes ranging from 14 to $590 \mathrm{~m}$ a.s.l., and to depths of 13.5-24 m. A conventional steam drill was used with an optimal pressure of $3.5 \mathrm{bar}$. One to three individually calibrated thermistors, with an accuracy of approximately $\pm 0.1^{\circ} \mathrm{C}$, were placed in each borehole, and measured manually from 1 to 11 times between 15 July 1990 and 27 July 1992.

The basal temperature of the winter accumulation was measured at 21 sites at different altitudes in May 1991. The measurements were made with a thermistor attached to a stake, the end of which had a low thermal conductivity. The temperature under a thick snow cover is known to be stable in late winter until the start of the surface melt (Haeberli 1973; Haeberli \& Patzelt 1982).

In permafrost mapping, such measurements are known as BTS-measurements (Basal Temperature of Snow). On Erikbreen the measurements were made to study the intensity of conductive cooling in late winter at the surface of the ice or firn.

\section{Results}

Along its centre flow line $85 \%$ of the glacier has an internal reflection horizon. The horizon becomes more diffuse upstream from the equilibrium line altitude and disappears close to site 9 at a depth of $30-40 \mathrm{~m}$. At higher elevations in the accumulation area an internal reflection horizon is not detected at the centre flow line, but distinct horizons are detected near the margins of the glacier along section 10 (Fig. 4) and the upper parts of section 8 (Fig. 5).

The largest depth of the internal reflection horizon along the centre flow line was $60 \mathrm{~m}$, occurring at site 7 just down glacier from the equilibrium line altitude. North of the centre flow line in section 3 the maximum depth was $90 \mathrm{~m}$ and in cross-section 5 it was $100 \mathrm{~m}$. In the ablation area below site 6 the depth of the horizon varies from 20 to $40 \mathrm{~m}$. The maximum slope of the horizon in section 3 was $35^{\circ}-40^{\circ}$.

Temperature measurements are given in Table 1 and Fig. 6. At the front of the glacier, at sites 1,2 and 3 , the measurements show a cold surface layer with a steep gradient at depth. Measurements from site 1 were not influenced by nearby crevasses. The temperature gradient between the two lowermost thermistors ranges from 0.18 $0.36^{\circ} \mathrm{C} / \mathrm{m}$ with an average of about $0.27^{\circ} \mathrm{C} / \mathrm{m}$. At site 3 a crevasse opened about one metre from the thermistor cable during the 1990/1991 winter. Interpretation of the site 3 data is therefore based solely on the 1990 summer temperature readings. 
320-370 MHz (water inclusions)
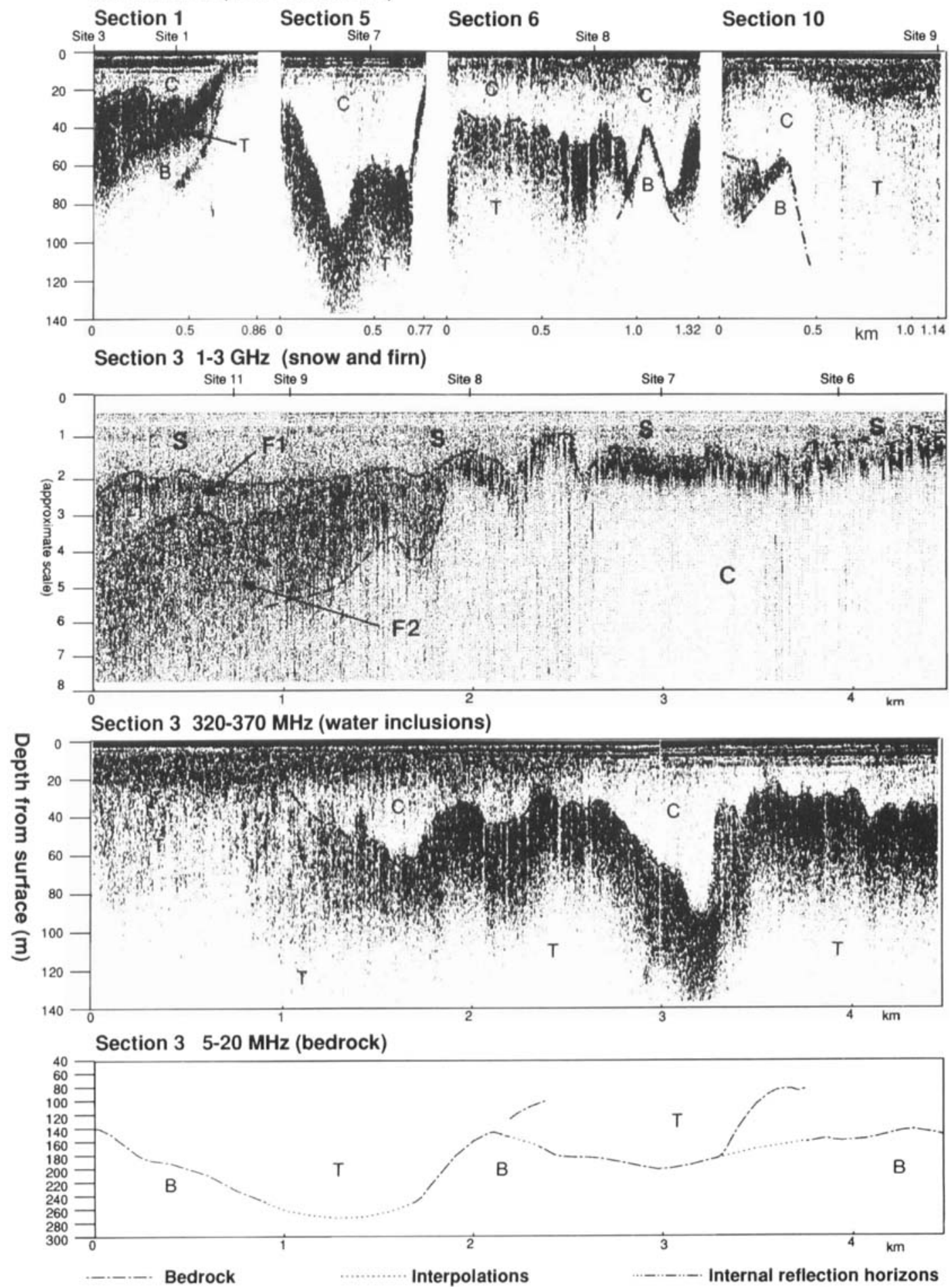

Fig. 4. Radar sections from Erikbreen with interpretations. $\mathrm{C}=$ cold ice. $\mathrm{T}=$ temperate ice. $\mathrm{B}=$ bedrock. $\mathrm{S}=\mathrm{snow}$. $\mathrm{Fl}=$ firn from summer 1990. F2 = older firn. The lower dashed line in the $1-3 \mathrm{GHz}$ image between sites 8 and 9 is believed to represent the lower level of meltwater percolation. In the $5-20 \mathrm{MHz}$ (bedrock) graph the shallow reflection at $2.25 \mathrm{~km}$ is interpreted to be reflection from the side of the valley. The shallow reflection between $3 \mathrm{~km}$ and $4 \mathrm{~km}$ is due to the radar section being measured north of the centre flow line close to the margin of the glacier (Fig. 2). Note different scales on ordinate. 
Sections 1, 3 and 4

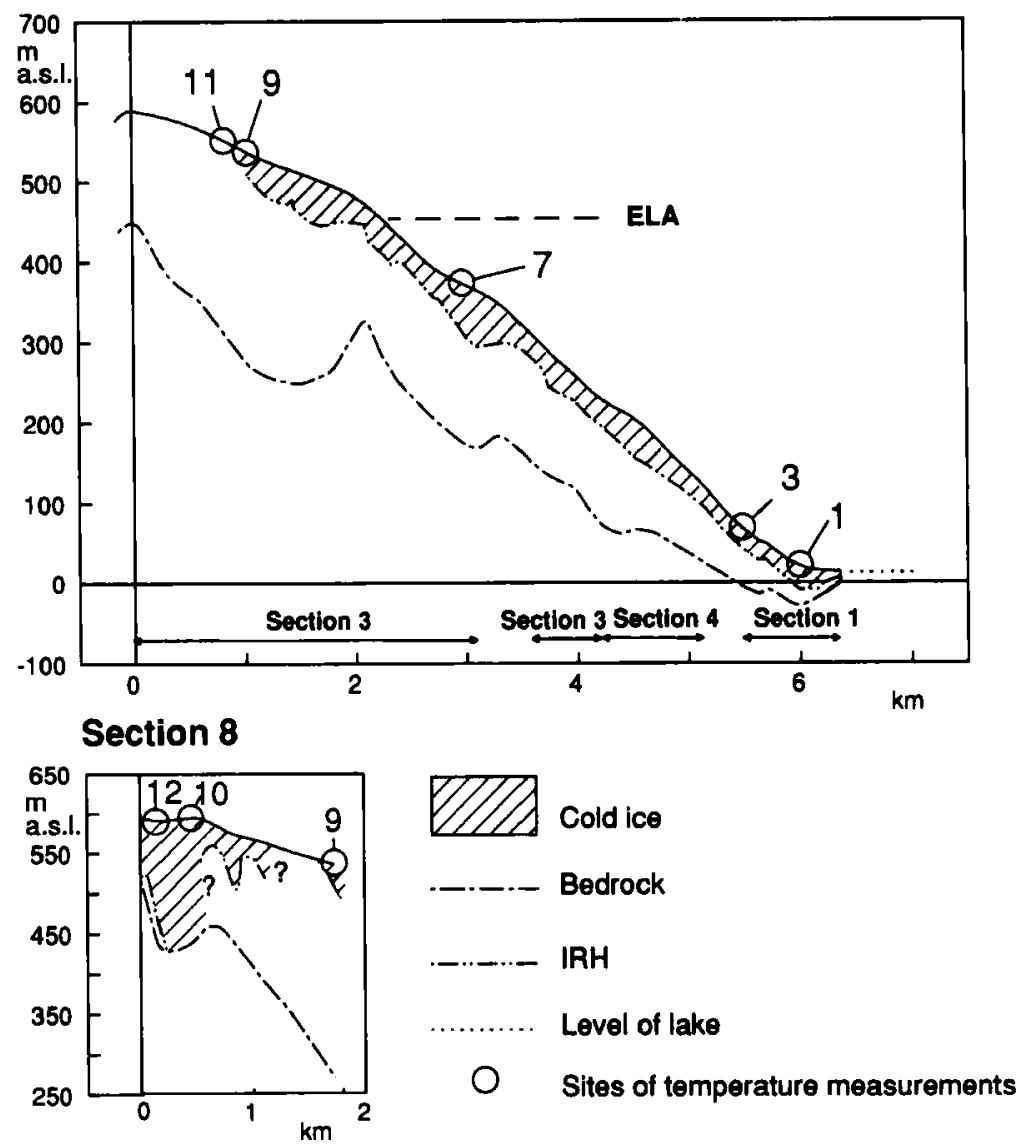

Fig. 5. Sections 1, 3 and 4 fall along the centre flow line of the glacier and show a layer of cold ice above a layer interpreted to be temperate ice. The centre flow line is partly interpolated (see lower part of figure). The interpolated parts are just downglacier site 7 and upglacier site 3 . Section 8 is located across the western parts of the accumulation area and show a zone interpreted to be cold based at high altitude. ELA = equilibrium line altitude. IRH $=$ internal reflection horizon.

At site 2 the deepest thermistor showed a rise in temperature during one year of $0.5^{\circ} \mathrm{C}$. The temperature gradient between the two lowermost thermistors at 14 and $19 \mathrm{~m}$ depth ranged from 0.14 to $0.18^{\circ} \mathrm{C} / \mathrm{m}$ in 1990 and from 0.26 to $0.28^{\circ} \mathrm{C} /$ $\mathrm{m}$ in 1991; such a rise was not detected at the other thermistor cables.

The temperature gradient at $10-15 \mathrm{~m}$ depth decreases significantly upglacier. At site 7 , close to the 1991 equilibrium line altitude, the temperature gradient between 10 and $15 \mathrm{~m}$ depth varied from 0.12 to $0.18^{\circ} \mathrm{C} / \mathrm{m}$. Results from site 9 at $536 \mathrm{~m}$ a.s.l. show that the maximum temperature gradients at depths from $8.5 \mathrm{~m}$ to $13.5 \mathrm{~m}$ in the spring of 1991 and 1992 were $0.06^{\circ} \mathrm{C} / \mathrm{m}$ and $0.04^{\circ} \mathrm{C} / \mathrm{m}$, respectively (Figs. 6 and 7 ). Late in the melt season the temperatures at these depths were about equal in all three years. At site 11, a single measurement in August 1991 showed a temperature of $0^{\circ} \mathrm{C}$ at $18 \mathrm{~m}$ depth. This is the only measurement documenting ice at pressure melting point below $10 \mathrm{~m}$ depth.

A temperature of $-5.4^{\circ} \mathrm{C}$ was recorded at $10 \mathrm{~m}$ depth at site 12, which lies in a depression in the accumulation area at $590 \mathrm{~m}$ a.s.l. (Fig. 5). In contrast, at site 10 , located $320 \mathrm{~m}$ from site 12 on a convex part of the glacier surface, a single measurement of $-0.9^{\circ} \mathrm{C}$ was found at $14 \mathrm{~m}$ depth.

The temperature at the base of the winter snow accumulation (BTS) in the spring of 1990 ranged from -5.4 to $-9.6^{\circ} \mathrm{C}$ and did not vary systematically with the elevation. Snow depths were from 0.85 to $2.3 \mathrm{~m}$ (Table 2). Measurements were made along the centre flow line at intervals of $150 \mathrm{~m}$ or $300 \mathrm{~m}$.

\section{Interpretation and discussion}

The mechanisms controlling the thermal regime of a subpolar glacier are a complex interaction of 


\begin{tabular}{|c|c|c|c|c|c|}
\hline & \multirow{3}{*}{ 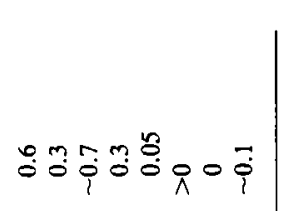 } & \multirow{3}{*}{\multicolumn{4}{|c|}{$\begin{array}{l}\text { (1) radiation; (2) heat conduction, advection and } \\
\text { production; and (3) non-steady state changes } \\
\text { (Paterson 1972; Hooke et al. 1983). The release } \\
\text { of latent heat by percolation and refreezing of } \\
\text { meltwater is an important internal heat source, } \\
\text { especially in the accumulation area (Sverdrup } \\
\text { 1935; Schytt 1969). }\end{array}$}} \\
\hline & & & & & \\
\hline & & & & & \\
\hline & \multirow{6}{*}{ 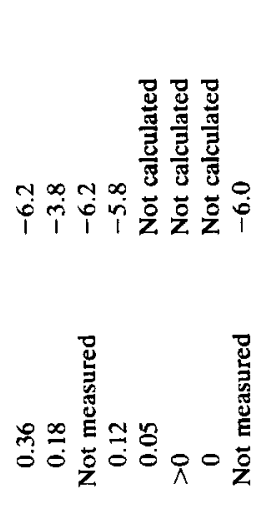 } & \multirow{7}{*}{\multicolumn{4}{|c|}{$\begin{array}{l}\text { In the interpretation of the radar images it } \\
\text { is assumed that the internal reflection horizon } \\
\text { represents the transition zone between cold and } \\
\text { temperate ice (Holmlund \& Eriksson 1989; } \\
\text { Bjørnsson et al. unpubl.). Due to limitations of } \\
\text { the drilling equipment, no temperature measure- } \\
\text { ments were made at depths below the internal } \\
\text { reflection horizon. Therefore, no definite con- } \\
\text { clusion can be made on this point on Erikbreen. } \\
\text { The results indicate that the glacier has a two- } \\
\text { layered thermal structure. The cold surface layer } \\
\text { starts upstream of the equilibrium line altitude } \\
\text { and appears to extend continuously all the way to } \\
\text { the front. It is underlain by a layer of temperate } \\
\text { ice. The formation of cold ice by freezing of } \\
\text { temperate ice at the base of the cold surface } \\
\text { layer is probably the main mechanism of cold ice } \\
\text { formation in the frontal parts of Erikbreen below } \\
\text { site } 6 \text {. In lower parts of the ablation area, at an }\end{array}$}} \\
\hline & & & & & \\
\hline & & & & & \\
\hline & & & & & \\
\hline \multirow{2}{*}{ 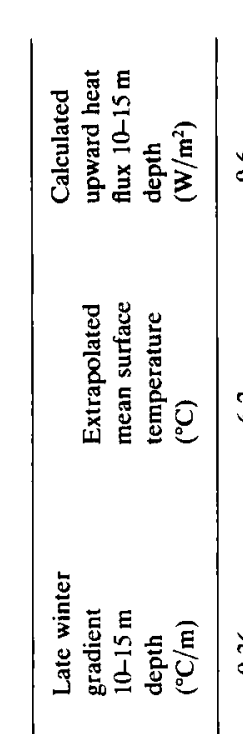 } & & & & & \\
\hline & & & & & \\
\hline \multirow{2}{*}{ 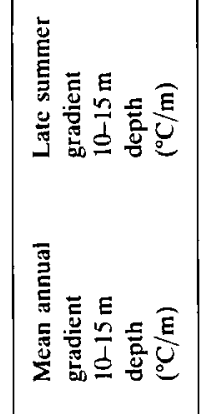 } & \multirow{2}{*}{ 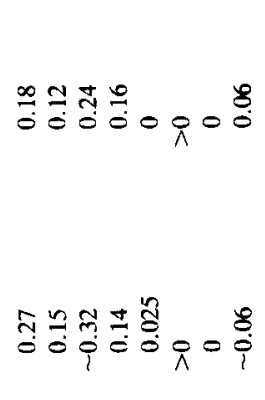 } & & & & \\
\hline & & \multicolumn{4}{|c|}{$\begin{array}{l}\text { Table 2. Surface temperature of ice/firn } 7 / 5-91 \text { (Basal tem- } \\
\text { perature of snow - BTS). }\end{array}$} \\
\hline \multirow{5}{*}{ | } & \multirow{3}{*}{ †ฺฺ } & $\begin{array}{l}\text { Approx. } \\
\text { altitude } \\
\text { m a.s.l. }\end{array}$ & $\begin{array}{l}\text { BTS } \\
\left({ }^{\circ} \mathrm{C}\right)\end{array}$ & $\begin{array}{l}\text { Snow } \\
\text { depth } \\
\text { (m) }\end{array}$ & $\begin{array}{l}\text { Interval } \\
\text { between } \\
\text { measurements } \\
\text { (m) }\end{array}$ \\
\hline & & 590 & -9.3 & 2.3 & \\
\hline & & 576 & -8.2 & 1.95 & 300 \\
\hline & & 562 & -8.3 & 2 & 300 \\
\hline & \multirow{6}{*}{ 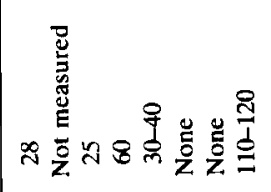 } & 548 & -8.6 & 2.1 & 300 \\
\hline \multirow{5}{*}{ 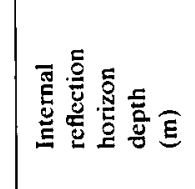 } & & 535 & -7.7 & 2 & 150 \\
\hline & & 527 & -7.9 & 1.95 & 150 \\
\hline & & 512 & -5.4 & 1.85 & 300 \\
\hline & & 497 & -7.6 & 1.8 & 300 \\
\hline & & 480 & -7.3 & 1.75 & 300 \\
\hline \multirow{6}{*}{ 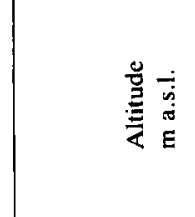 } & \multirow{5}{*}{ 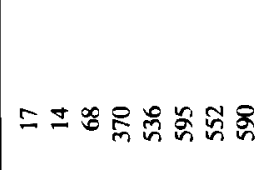 } & 430 & $\begin{array}{l}-9.6 \\
-7.3\end{array}$ & & \\
\hline & & 369 & -7.9 & 1.7 & $\begin{array}{l}300 \\
300\end{array}$ \\
\hline & & 351 & -7.5 & 1.5 & 300 \\
\hline & & 337 & -6.5 & 1.55 & 300 \\
\hline & & 315 & -6.6 & 1.45 & 300 \\
\hline & & 270 & -6.5 & 1.5 & \\
\hline \multirow{4}{*}{ 总 } & \multirow{4}{*}{$-\operatorname{nmtag}=2$} & 221 & $\begin{array}{l}-8.0 \\
-8.2\end{array}$ & $\begin{array}{l}1.2 \\
1.25\end{array}$ & $\begin{array}{l}300 \\
300\end{array}$ \\
\hline & & 205 & -8.1 & 1.15 & 150 \\
\hline & & 163 & -7.3 & 1.02 & 300 \\
\hline & & 118 & -7.7 & 0.95 & 300 \\
\hline
\end{tabular}



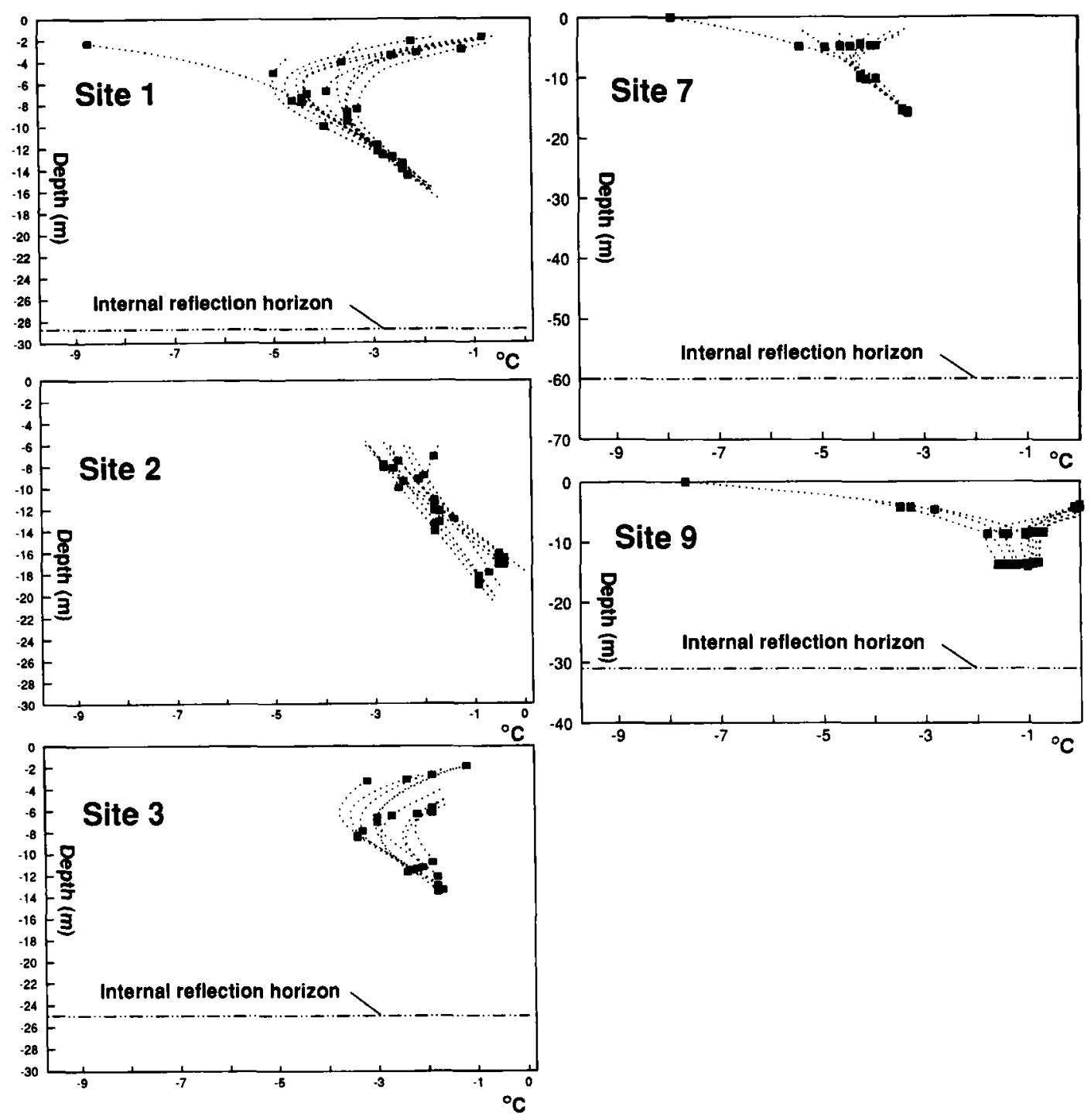

Fig. 6. Plots of temperature measurements in boreholes. Depths of measurements arc adjusted for surface melt or accumulation, so they are approximate depths at times of measurement. The dotted lines are coarse interpolations and extrapolations. Dash double dot lines are internal reflection horizons bclicved to mark the base of the cold layer. Note different scales on ordinate. Original depth of thermistors: site $1: 4 \mathrm{~m}, 9.5 \mathrm{~m}$ and $14.5 \mathrm{~m}$; site $2: 10 \mathrm{~m}, 14 \mathrm{~m}$ and $19 \mathrm{~m}$; site $3: 3.8 \mathrm{~m}, 9 \mathrm{~m}$ and $14 \mathrm{~m} ;$ site $7: 5 \mathrm{~m}$, $10.25 \mathrm{~m}$ and $15.75 \mathrm{~m}$; site $9: 4 \mathrm{~m}, 8.5 \mathrm{~m}$ and $13.5 \mathrm{~m}$.

altitude below site 6 (Fig. 2), the continuous cold surface layer is interpreted to be 20 to $40 \mathrm{~m}$ thick. The surface melt is about $1.0 \mathrm{~m} / \mathrm{y}$ at site 6 , increasing to $1.7 \mathrm{~m}$ and $2.3 \mathrm{~m}$ at the terminus; surface ice velocities are about 30 to $45 \mathrm{~m} / \mathrm{y}$. The rates of surface melt, surface ice velocities and the measured ice temperatures indicate that the thermal conditions in the frontal parts are at or close to equilibrium. Assume that the thickness of the cold layer is controlled by mean surface temperature, surface melting and water content in the transition zone between cold and temperate ice. In such a model a steady state is possible, where the conductive heat transfer in the cold surface layer is sufficient to freeze temperate ice at depth at the same rate as surface melting.

For example, at site 1 the lower thermistor shows a decrease in temperature of $0.6^{\circ} \mathrm{C}$ between 
Fig. 7. Time series of the temperature measurements at site 9. Dashed lines are coarse interpolations.

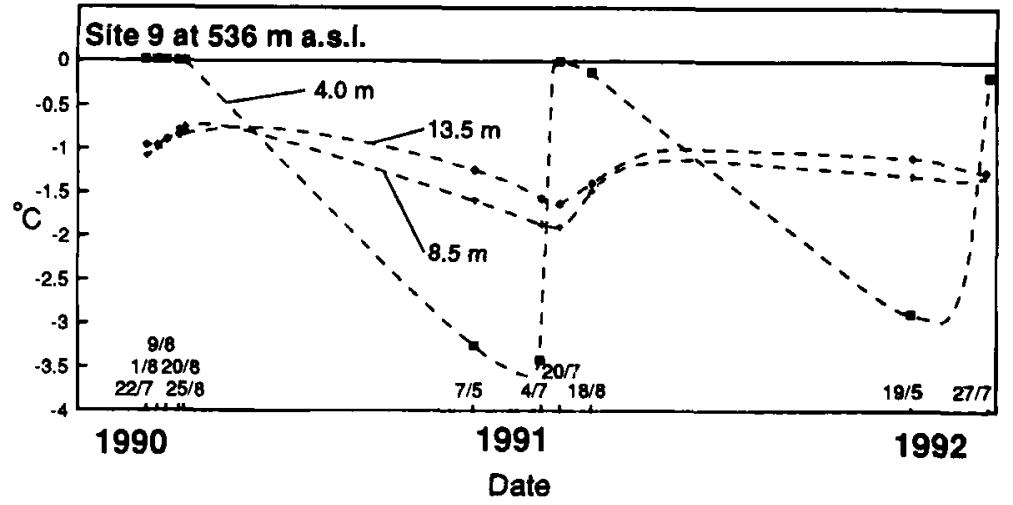

1990 and 1991; the mean ablation rate is about $1.7 \mathrm{~m} / \mathrm{y}$. The yearly average gradient between the lowermost two thermistors was $0.27^{\circ} \mathrm{C} / \mathrm{m}$. The thermal conductivity of ice is $2.1 \mathrm{~W} / \mathrm{mK}$ (Paterson 1981). Thus the mean annual upward heat flux is about $0.57 \mathrm{~W} / \mathrm{m}^{2}$ at 10 to $15 \mathrm{~m}$ depth. For the base of the cold layer to move downward at a rate of $1.7 \mathrm{~m} / \mathrm{y}$, equal to the ablation rate, the water content of the ice would have to be $3.1 \%$.

Bamber (1987a) states that a thermally regulated boundary would be expected to be smooth on a $10 \mathrm{~m}$ scale. The irregular appearance found on Erikbreen can be explained by local variations in water content, which have a strong influence on the propagation of a freezing front.

If the gradient at depth is extrapolated to the surface, the mean surface temperature can be calculated to be about $-6.2^{\circ} \mathrm{C}$ and the depth of the cold layer $23 \mathrm{~m}$. These are probably underestimates. Because ice is constantly cooled as surface melting causes its depth in the glacier to decrease, the amount of heat moving upward through the ice increases towards the surface (Hooke 1977). Thus the temperature gradient is expected to decrease with depth. Radio-echo data indicate a cold ice thickness of $28 \mathrm{~m}$, which also implies a lower gradient at depth. Since a lower gradient is expected at depth, the water content calculated above is a maximum.

Measurements of water content on Svalbard glaciers are few. In a deep borehole on Fridtjovbreen an internal reflection horizon was associated with temperate ice with a water content of $1-2 \%$ (Glazovsky \& Moskalevsky 1989). Bamber (1987a) suggests a water content of $>3 \%$ based on interpretation of radio-echo data.

At site 3 the measured late summer temperatures in 1990 suggest a gradient of about $0.24^{\circ} \mathrm{C} / \mathrm{m}$ compared with $0.18^{\circ} \mathrm{C} / \mathrm{m}$ at site 1 . A steeper gradient at site 3 is consistent with the larger surface melt at this site.

Observations at site 2 do not fit into the steady state model. A rise in temperature of $0.5^{\circ} \mathrm{C}$ at $17-$ $19 \mathrm{~m}$ depth from 1990 to 1991 cannot be explained by heat conduction from the surface. The rise could be due to crevasses that formed in 1991, admitting meltwater, or the melting of cold ice under the floating front of the glacier. This site probably began to float during the 1990 season. Radar-echo sounding was not attempted in this area. The depth of the lake in front of site 2 was $25 \mathrm{~m}$ in 1990 , which gives an approximate maximum thickness of the glacier. The bottom of the glacier was not reached by drilling to $19 \mathrm{~m}$ depth in 1990.

Just below the equilibrium line altitude there are low rates of surface melt. Here a non-steady state is expected with an increasing cold layer thickness. An increase in thickness from 30 to $60 \mathrm{~m}$ is found just upglacier of site 7 . The temperature gradient at $10-15 \mathrm{~m}$ depth is about half the values at sites 1 and 3 . These observations may be a result of freezing at the base of the cold layer, but the local ice flow regime is probably of importance. The latter is supported by the steep slope of the internal reflection horizon in this area.

That the cold surface layer extends upglacier from the equilibrium line altitude is supported by temperature measurements at site 9 (Fig. 7), where cold ice was detected in the melting season in 1990, 1991 and 1992 at depths of $8.5 \mathrm{~m}$ and $13.5 \mathrm{~m}$ (Fig. 7). The diffuse backscatter at 30 $40 \mathrm{~m}$ depth could be explained by a wide transition zone from cold to temperate ice. Observations suggest a mean annual temperature gradient at $10-15 \mathrm{~m}$ depth of just $0.02-0.03^{\circ} \mathrm{C} / \mathrm{m}$. Thus freezing at the base of the cold surface layer is a less 
important process here, and the thickness of the cold layer is probably mainly controlled by the actual accumulation of cold ice and vertical ice movements.

Cold ice cannot survive in the accumulation area if summer meltwater percolates through the level of the winter cold wave and refreezes. Based on the thermistor measurements and BTSmeasurements at site 9 in the spring of 1991, the energy needed to bring the surface layer of firn to $0^{\circ} \mathrm{C}$ can be calculated. Beneath a $2 \mathrm{~m}$ snow cover the temperature was $-7.7^{\circ} \mathrm{C}$, at $4 \mathrm{~m}$ depth $-3.3^{\circ} \mathrm{C}$, and at $8.5 \mathrm{~m}$ depth $-1.5^{\circ} \mathrm{C}$. A rough calculation including a snow pack of $2 \mathrm{~m}$ with a temperature of $-15^{\circ} \mathrm{C}$ shows that the snow pack and the upper $8.5 \mathrm{~m}$ of firn/ice could have frozen $0.20 \mathrm{~m}$ to $0.25 \mathrm{~m}$ of meltwater in 1991 . The total ablation at this site in 1991 was $0.34 \mathrm{~m}$. Thus even in a year of minimum surface melt such as this, latent heat released from refreezing of available meltwater is potentially more than that needed to bring the surface layer to $0^{\circ} \mathrm{C}$. The high altitude areas of Erikbreen are probably not in the cold firn zone as are high altitude areas in the Alps (Haeberli 1976).

Low permeability at depth is probably responsible for temperatures below zero at low altitudes in the accumulation area. Low permeability can be caused by a fast transformation of snow to ice by melting and refreezing or by formation of ice lenses. The former is supported by the high resolution $1-3 \mathrm{GHz}$ radar image of the surface layer (Fig. 4) that shows a change in the surface conditions along the section from site 8 to site 9 . The diffuse scatter at depths from 2 to $8 \mathrm{~m}$ above site 8 is believed to represent firn. At site 9 the scatter from firn disappears below 5 to $6 \mathrm{~m}$ depth. Ice of low permeability is interpreted to exist below this depth.

The $320-370 \mathrm{MHz}$ radar images indicate a complicated thermal regime at higher elevations in the accumulation area. Cold-based ice is interpreted to exist locally in sections 8 and 10 (Figs. 4 and 5). Thus within a few hundred metres of each other there are areas interpreted to be temperate throughout, cold throughout and temperate with a cold surface layer. In the upper parts of section 8 the interpretation of the radar image indicates cold-based ice with a minimum ice thickness of $150 \mathrm{~m}$ (Fig. 5). The ice surface gradients and the subglacial topography indicate stagnant ice or very small movements transverse to the radar section.

\section{Conclusions}

The cold surface layer on Erikbreen extends from the terminus upglacier to the lower parts of the accumulation area. A local zone of cold surface ice is also documented at higher elevation in the accumulation area. Cold ice may be formed in the accumulation area because of the low permeability of the surface layer, which inhibits percolation of summer meltwater.

The interpretation of the internal reflection horizon as the top of the temperate ice (Holmlund \& Eriksson 1989; Bjørnsson et al. unpubl.) is supported by the observed temperatures on Erikbreen, but no measurements were made beneath the internal reflection horizon.

Measured temperature gradients and calculations of heat flow show that large heat fluxes can exist in the cold surface layer of subpolar glaciers (Table 1). Close to the glacier front the mean annual upward heat flux at $10-15 \mathrm{~m}$ depth is estimated to be about $0.6 \mathrm{~W} / \mathrm{m}^{2}$. In view of these large near-surface temperature gradients, heat loss of this order can freeze temperate ice at the base of the cold upper layer at the same rate as surface melting if the water content is maximum $3 \%$. Close to the equilibrium line altitude and in the lower parts of the accumulation area, freezing at the base of the cold layer is probably less important.

Acknowledgements. - This study was conducted as part of the project "Stofftransport Land-Meer in polaren Geosystemen" SPE $90-92$ coordinated by W. D. Blümel. The German "Arbeitskreis für Polargeographie" initiated the project. Special thanks are expressed to $O$. Liestøl for advice during preparation of the field work and R. Leb. Hooke, who reviewed the manuscript and gave constructive comments.

Financial support was provided by the Deutsche Forschungsgemeinschaft (DFG), the Norwegian National Committee for Hydrology (NHK), Norsk Polarinstitutt (stipend 11/ 91 and 16/92) and Norsk Hydro A/S. The Norwegian Coast Guard helped with transportation. The data were compiled at the Department of Physical Geography, University of Oslo.

\section{References}

Bamber, J. L. 1987a: Internal reflecting horizons in Spitsbergen glaciers. Annals of Glaciology 9, 5-10.

Bamber, J. L. 1987b: Radio echo sounding studies of Svalbard glaciers. Unpublished Ph.D. thesis. Jesus College, University of Cambridge. 207 pp.

Dowdeswell, J. A., Drewry, D. J., Liestøl, O. \& Orheim, O. 1984a: Radio-echo sounding of Spitsbergen glaciers: problems in the interpretation of layer and bottom returns. Journal of Glaciology 30 (104), 16-21.

Dowdeswell, J. A., Drewry, D. J., Liestøl, O. \& Orheim, O. 
1984b: Airborne radio echo sounding of sub-polar glaciers in Spitsbergen. Norsk Polarinstitutt Skrifter 182. 41 pp.

Etzelmüller, B., Vatne, G., Ødegård, R. S. \& Sollid, J. L. 1993. Dynamics of two subpolar glaciers - Erikbreen and Hannabreen, Liefdefjorden, northern Spitsbergen. Geografiska Annaler. In press.

Glazovsky, A. F. \& Moskalevsky, M. Yu. 1989: Issledovaliya lednika Fritjof na Spitsbergene v 1988 godu (The studies of Fridtjovbreen in Spitsbergen in 1988). Materialy Glyatsiologicheskikh Issledovaniy 65, 148-153.

Haeberli, W. 1973: Dic Basis-Temperatur Der Winterlichen Schneedecke als Möglicher Indikator Für Die Verbreitung Von Permafrost in Den Alpen. Zeitschrift für Gletscherkunde und Glazialgeologie 9 (1-2), 221-227.

Haeberli, W. 1976: Eistemperaturen in Den Alpen. Zeitschrift für Gletscherkunde und Glazialgeologie 11 (2), 203-220.

Haeberli, W. \& Patzelt, G. 1982: Permafrostkartierung im Gebiet Der Hochebenkar-Blockgletscher, Obergurl, Ötztaler Alpen Zeitschrift für Gletscherkunde und Glazialgeologie 18 (2), 127-150.

Hagen, J. O. \& Liestøl, O. 1990: Long-term glacier massbalance investigations in Svalbard 1950-88. Annals of Glaciology 14, 102-106.

Holmlund, P. \& Eriksson, M. 1989: The cold surface layer on Storglaciären. Geografiska Annaler 71A (3-4), 241-244

Hamran. S. E. 1989: Geophysical electromagnetic backscatter tomography. Experimental result from glacier study. Ph.D. thesis. University of Tromsø. $126 \mathrm{pp}$.

Hooke, R. LeB. 1977: Basal temperatures in polar ice sheets: a qualitative review. Quaternary Research 7, 1-13.

Hooke, R. LeB., Gould, J. E. \& Brzozowski, J. 1983: Nearsurface temperatures near and below the equilibrium line on polar and subpolar glaciers. Zeitschrift für Gletscherkunde und Glazialgeologie 19(1), 1-25.
Kotlyakov, V. M. \& Macheret, Y. Y. 1987: Radio-echo sounding of sub-polar glaciers in Svalbard: some problems and results of Soviet studies. Annals of Glaciology 9, 151-159.

Lefauconnier, B. \& Hagen, J. O. 1990: Glaciers and climate in Svalbard: statistical analysis and reconstruction of the Brøggerbreen mass balance for the last 77 years. Annals of Glaciology 14, 148-152.

Liestøl, O. 1976: Pingos, springs, and permafrost in Spitsbergen. Norsk Polarinstitutt Arbok 1975, 7-29.

Liestø1, O. 1988: The glaciers in the Kongsfjorden area, Spitsbergen. Norsk Geografisk Tidsskrift 42, 231-238.

Nixon, W. A., Dowdeswell, J. A., Cooper, A. P. R., Drewry, D. J., Watts, L. G., Liestøl, O. \& Smith, R. A. 1985; Applications and limitations of finite element modeling to glaciers: a case study. Journal of Geophysical Research 90 (B13), 11303-11311.

Paterson, W. S. B. 1972: Temperature distribution in the upper layers of the ablation area of Athabasca Glacier, Alberta, Canada. Journal of Glaciology 11 (61), 31-41.

Paterson, W. S. B. 1981: The Physics of Glaciers, 2nd Edition. Pergamon Press. 380 pp.

Schytt, V. 1969: Some comments on glacier surges in eastern Svalbard. Canadian Journal of Earth Sciences 6, 867-873.

Smith Ewen, B. M. \& Evans, S. 1972: Radio echo sounding: absorption and scattering by water inclusion and ice lenses. Journal of Glaciology 11 (61), 133-146.

Sverdrup, H. U. 1935: The temperature of the firn on Isachsen's Platau, and general conclusions regarding the temperature of the glaciers on West-Spitsbergen. Geografiska Annaler 17, 51-88.

Vatne, G., Etzelmüller, B., Ødegård, R. S. \& Sollid, J. L. 1992: Glaciofluvial sediment transfer of a subpolar glacier, Erikbreen, Svalbard. Stuttgarter Geographische Studien 117, 253-266. 